UDC 330.101

JEL Classification: 010, 040

http://doi.org/10.21272/mmi.2019.3-18

Cristina Gabriela Cosmulese,

Ph.D., Stefan cel Mare University, Romania

Veronica Grosu,

D.Sc., Professor, Stefan cel Mare University, Romania

Elena Hlaciuc,

D.Sc., Professor, Stefan cel Mare University, Romania

Artur Zhavoronok,

Ph.D., Associate Professor, Yuriy Fedkovych Chernivtsi National University, Ukraine

\title{
THE INFLUENCES OF THE DIGITAL REVOLUTION ON THE EDUCATIONAL SYSTEM OF THE EU COUNTRIES
}

Abstract. In the context of the information skills development programs that are being developed by the EU, there is an increasing interest in the acquisition and use of digital competences as an impact factor on the educational system at all its was levels. The present study aims to analyze the evolution of digital specializations generated by the digital evolution, in parallel with the development of the educational system, through a statistical analysis of the main indicators that have been reported at EU level on early education abandonment, employment rate of graduates, employment of IT specialists by gender, adult participation in gender-based learning, and other impact indicators that demonstrate the capacity of the population in the digital domain through the use of ICT solutions. The object of research were the statistical indicators reported for 2017 by Eurostat at the level of the European Union, for each member state of the union, obtaining a total of 29 statistical observations. The data were modelled through the GRETL statistical program, obtaining a model based on the smallest squares method in 2 phases. This paper shows that there is a need to assimilate the European approaches in the field of digital evolution, a necessity which varies according to the economic development of each member state, Romania being ranked in the chapter of assimilation of the objectives of the open education agenda in the second part of the European ranking, including based on the low absorption rates provided for Union programs in this area. The study theoretically proves and empirically confirms that the function obtained through modelling can be assimilated to the service demand function and can be integrated into the offer function harmonized with the information factor. This research study represents a contribution to the field of management of public utility companies and can be useful for educational institutions, students, the labour market and the general public, providing a starting point for further indepth research in this area.

Keywords: educational system, digital revolution, economic development, EU Agenda.

Introduction. The European Agenda on stimulating innovative and high-quality teaching and learning methods through New Technologies and digital content, generically called «the opening of education», brings to light measures for boosting competitiveness and economic growth at EU level, through the use of a highly skilled workforce with objectives, especially in the area of competence growth, limiting social phenomena such as unemployment, social discrimination and through increasing equality of opportunity. Another goal of the 'Open Education' agenda is the achievement of the European Union's objectives in terms of reducing early school leaving and increasing tertiary education. Recent studies have shown that, at a cognitive level, a significant proportion (70\%) of teachers in the European education system recognize the importance of teaching based on digitally assisted methods, but practically, only $25 \%$ of the teaching staff use digital assisted methods in working with the beneficiaries of the training. At the level of didactic preparation (the conception of pedagogical materials) there is a high rate of use of Information and Communication Technologies by the professor, meaning that most of the teaching material is created on the basis of ICT (Ciubotariu, 2011; Togoe et al., 2013; Mihaila \& Badicu, 2016). The implementation of digital solutions has a coverage rate in the specific market of only

Cite as: Cosmulese, C.G., Grosu, V, Hlaciuc, E., Zhavoronok, A. (2019). The Influences of the Digital Revolution on the Educational System of the EU Countries. Marketing and Management of Innovations, 3, 242-254. http://doi.org/10.21272/mmi.2019.3-18 
C. G. Cosmulese, V. Grosu, E. Hlaciuc, A. Zhavoronok. The Influences of the Digital Revolution on the Educational System of the EU Countries

50 to $60 \%$, a critical mass shortage of high-quality educational content based on the use of ICT being found at this level, including the lack of ICT infrastructure in education units. The main advantage of using digital assisted methods is represented by an increase in the availability of information on the two axes of time and place, open technologies enabling anyone to learn anywhere, anytime with or without the support of a specialist teacher.

The transfer of information without frontiers is facilitated by digital technology, creating the premises of the plus-value of the educational activities through the optimization of information and the exploitation of the potential for international cooperation. Another advantage derived from the implementation of the digital revolution and the «Open Education - Orizont 2020» agenda is the access to training facilities for the international population mass with educational training needs in the sense that through the implementation of the agenda targets, the number of students with an impact on attracting funding sources, the reduction of fixed costs for educational institutions and the creation of new jobs in education can increase.

At the same time, the use of electronic teaching materials also has a beneficial impact on the environment, reducing the consumption of biological resources necessary for the production of printed materials.

In this context, the European Union, through its decision-making fora, acted through Member State funding programs on digitization and ICT acquisition, programs that make a significant contribution to stimulating thinking and developing creativity among people undergoing educational training. Through these interactive digital modes, it is possible to reduce the effort made by teachers to provide information and maximize the amount of information that is useful to learners, all in a very short time.

Among the key concerns for the EU's policy agenda in the field of education, the question of whether digital natives are also digital-savvy also occurs. In this case, we have also compiled comparing computer and information literacy across and within countries, and one of the findings can be seen in the graph below:

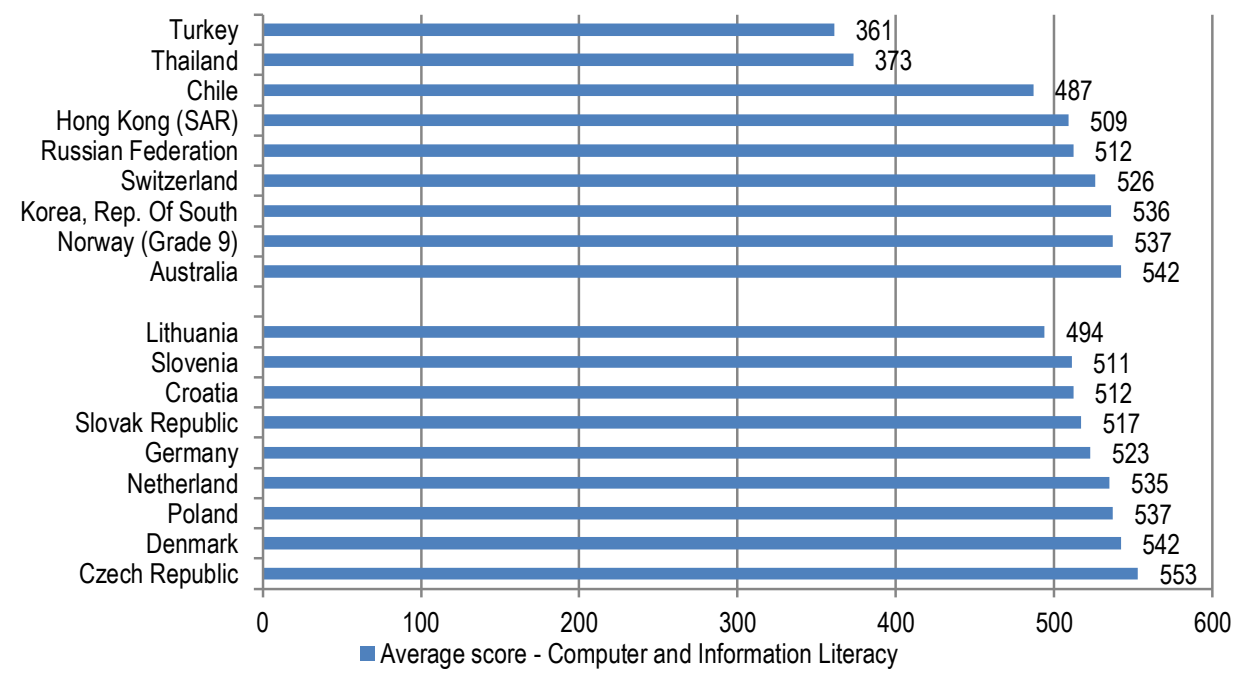

Figure 1. Average score - Computerandinformationliteracyscale

Source: IEA (ICILS, 2013).

Digital learning is a «distance learning», allowing access to information, images and all information 
C. G. Cosmulese, V. Grosu, E. Hlaciuc, A. Zhavoronok. The Influences of the Digital Revolution on the Educational System of the EU Countries

digitally transposed on any electronic device, regardless of space and/or time. An overview of the penetration rate in the main regions of the world, reported at the end of 2017 , can be seen in the chart below:

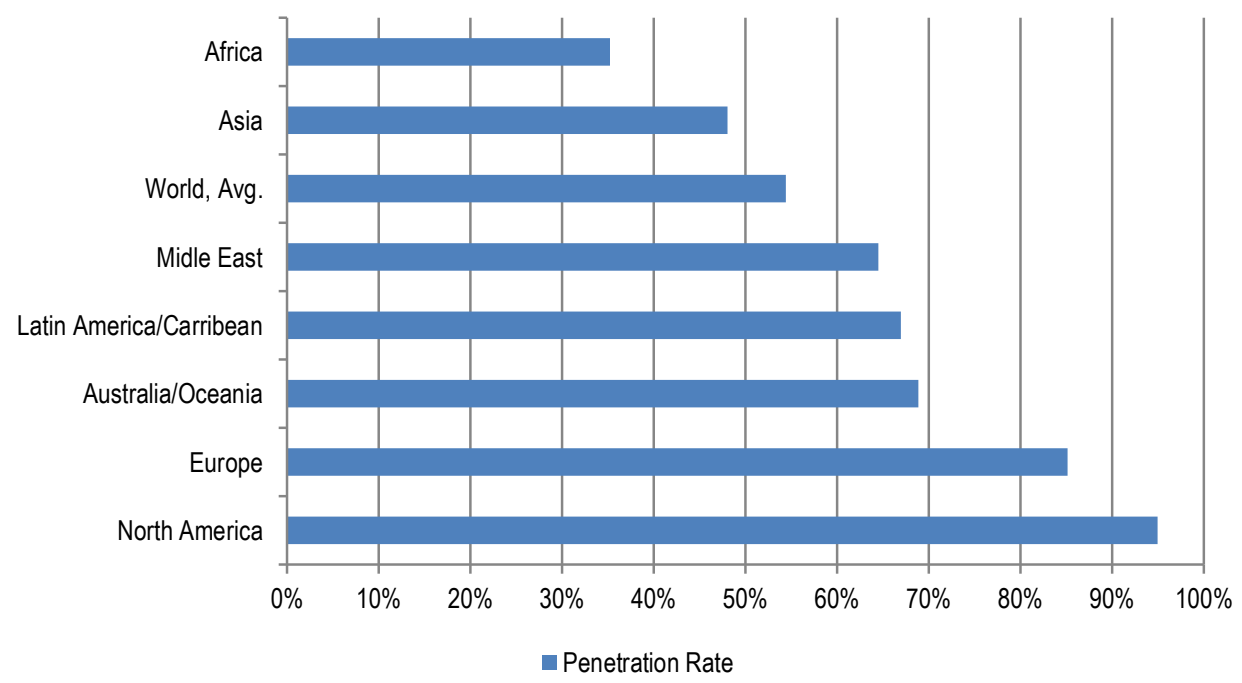

Figure 2. Internet World penetration Rates by Geographic regions (December 31, 2017)

*The penetration rate is based on a world population of 7,634,758,428 and 4,156,932,140 estimated Internet Source user on December 31, 2017.

Source: adapted from www.internetworldstats.com/stats.htm, (Internet Users in the world by Regions, 2019).

Prestigious universities have included this interactive method of information transfer - e-learning - in their educational offer, which can be a factor for attracting categories of potential learners who prefer to avoid physical movement to deepen the courses (Nastase, 2012; Benta et al., 2015; Badicu \& Mihaila, 2016).

Literature Review. The expression of digital literacy was first used by Gilster (1997) in a volume called Digital Literacy, in which this competence was defined as accentuating critical thinking skills and assessing information more than technical and procedural skills. Within 20 years of distance, however, numerous research studies on the subject, as well as the definition of these skills occurred (Bennett et al., 2008; Shariman et al., 2012; Goulão \& Fombona, 2012; Saubari \& Baharuddin, 2016).

The theme of digital literacy has grown over the past twenty or thirty years to a great extent, alongside the digitization of most of the entity's business activities, while at the same time assuming an increasingly important role in educational management in the new millennium.

On the other hand, the theme of digital natives was debated for the first time by Prensky (2001), which argues that a digital environment dramatically changes the way people think and process information - possibly even altering their brain structure.

Why is this theme so important today? Answers to this question may indicate at least two main reasons. Firstly, it is a mandatory passage for a more conscious selection of why and how to use new technologies in schools. On the other hand, we face a socio-cultural process that involves from the inside a cognitive infrastructure that is responsible for the acquisition and treatment of basic information and knowledge, ie a process of redefining «literacy» (Calvani et al., 2009; Burciu \& Kicsi, 2015). 
C. G. Cosmulese, V. Grosu, E. Hlaciuc, A. Zhavoronok. The Influences of the Digital Revolution on the Educational System of the EU Countries

Pupils and students from schools and universities in the European countries which, most of them, have become almost digitally native, are trying to cross the boundaries of two different temporal worlds every day: on the one hand high-interactivity and connection environments currently using the digital code; and on the other hand, learning environments still linked to the alphabetical code. In this context, Ferri (2013), draws attention to the importance of the teaching activities and its new components, such as re-evaluating the «learn by doing» act that can be available to anyone. As a consequence, students and students today think and process information totally different from their predecessors.

Horizon Report Europe (2014) also draws attention to the digital competences of children and adolescents in Europe as remaining inadequate. This trend is particularly relevant for the critical and participatory literacy method when students need not only to read the content but also to engage with it and to actively create their own responses. According to the European Commission $(2014 ; 2018)$, due to these trends, there is a risk that Europe will experience severe drops of trained citizens in the digital age, thus hindering economic growth and competitiveness. Digital literacy skills have a huge impact on lifelong learning processes in terms of accessing to right information by using reliable information resources; therefore, it is increasingly gaining a vital role (Çakmak et al., 2013). There are authors who insist on the importance of open educational resources considered to be essential to equip young learners with new sets of occupational and life skills; it is not like some of the longer learning resources created for university students, but it is open to the public as well as being of use to current students (Das, 2011).

Open access resources can be considered as an innovative development in their own right as the open licensing inherent in those enables content and technology creators to make their content or technologies more available and accessible to more people than would otherwise be the case. Through the daily use of new information and communication technologies, implementation in practice means strengthening a sustainable educational process that raises new requirements in terms of learning technologies and methods. Over the past twenty years, this theme has been addressed in a number of manners, which eventually led to an enhancement of experience and approach to the use of ICT for educational purposes. In practice, an alternative learning option is currently learning on the internet in order to meet educational demand, its use increasing proportionally with the increasing number of students (Samir Abou El-Seoud et al., 2014; Kakoty, 2011). Cognitive society is, at the same time, an individualized society. A major idea associated with the use of ICT is that of pedagogy of individualization, as by introducing ICT in education we are actually talking about establishing a new cultural logic (Fat \& Vlada, 2012). The digitalization of education keeps the students in-sync with the contemporary world. Student can get the feeling of being in a virtual class anywhere anytime, without being burdened by the sheer weight of books. Online learning also provides many additional benefits beyond convenience and financial savings (Ahuja, 2015).

Thus, in the informational age, technology education gains new valences, being a basic component of the modern education system. A number of positive aspects of the use of new information technologies are listed by lancu (2005), namely: transforming the way we communicate; Transforming the way we have information; Changing the way we learn; Transforming the nature and the way we trade; Changing the way we work; Transforming the way we design and manufacture goods, etc.

The study of educational, research and innovation components on the processes of information economy development is analyzed to formulate conclusion on the significant prospects of science and higher education in enhancing the information economy of the countries of the Eastern Partnership need to synchronize the interests of institutions of higher education and business, which will allow to stimulate the development and implementation of innovative research results of universities in a real segment of the national economy and thus accelerate the formation rate of the information economy in the country (Shkarlet et al., 2019). 
C. G. Cosmulese, V. Grosu, E. Hlaciuc, A. Zhavoronok. The Influences of the Digital Revolution on the Educational System of the EU Countries

All these effects are already felt in society and the paradigm we are talking about at the level of economic development is determined, among other things, by the following characteristics: a new skills profile of the workforce that radically changes the quality and quantity of work and, implicitly, redistributes revenue; the rapid entry into the economic activity of small innovative firms that expand the field of activity of the existing branches or, in many cases, generate new sectors of the economy; intensive substitution of costly past production factors with a new key factor ((Dicusar \& Dicusar, 2011); Socoliuc, 2016a). This industry is fundamentally different from its predecessors, as it is a revolution of networks, platforms, people and digital technology. The rapid evolution of technology makes it necessary for education to keep pace because mechanical and repetitive work has been taken over by machinery and technology. So the new labour market now requires people to focus on ingenuity, to understand and to create new things (Socoliuc, 2016a).

Methodology and research methods. For statistical analysis on the impact of IT on the educational system, data reported by Eurostat were analysed regarding the following indicators:

a) the vacancy rate among the young population;

b) the tertiary education system for the population aged 30-34;

c) early school leaving according to the gender of the participants;

d) the employment rate among graduates;

e) the level of early aged education as a percentage of inhabitants per EU Member State;

f) the level of employment of ICT specialists.

This information allowed for the strengthening of the data relevant to the studied phenomenon in the period 2013-2017, as follows:

a) Regarding the NEET youth, depending on the gender of the participants, it is found that the average rate at U.E. is $13.5 \%$ with a less favourable distribution to women in the sense that among the population aged 18-24, the female population shows a higher frequency of vacancy both in the workplace and the non-participation to the act of education than men.

Compared to the European average, the lowest vacancy rate is found in the Netherlands, where the trend of distribution is reversed, meaning that in this country the male population aged 18-24 is the disadvantaged one, with the gender difference being $14 \%$ over the male sex (5.6\% versus $4.9 \%)$. Other countries with low rates of school drop-out and non-employment are Austria, the Czech Republic, Malta and Slovenia. In the case of the Czech Republic, the average vacancy distribution is $8.3 \%$, but the imbalance in favour of the female population is $95 \%$, which proves a phenomenon of gender inequality in the reference country. The same phenomenon is manifested in Hungary and Romania, countries where the imbalance between the two sexes is $91 \%$ (Hungary) and $51 \%$ (Romania). The case of Romania is one with a $43 \%$ higher intensity than the European average, imposing measures of social inclusion of unoccupied and unintegrated people in a form of education for the age group of 18-24 years, which, according to Eurostat figures, reach almost $20 \%$ of the total population of Romania.

The most disadvantaged situations are not met in Romania, but in Italy $(25.7 \%)$, Cyprus (22.7\%) and Croatia $(22.2 \%)$.

b) The level of tertiary education analysed on the 30-34 age group provides information on the preoccupation for professional reconversion of the preoccupation for continuous professional training, and is situated at a fairly high level in the European Union at $37 \%(2013)$ to around $40 \%$ (2017), as shown in figure 3 below.

The best ratings of the tertiary education level are shown in countries such as Ireland, Lithuania, Luxembourg. Moreover, compared to the EU average target of $40 \%$, Ireland and Luxembourg have a national target of 60 and $66 \%$, respectively. The average values for 2017 for these three countries exceed the European Union figure of 32 to $45 \%$, with average values of $53.5 \%$ for Ireland, $58 \%$ for Lithuania, and $52.7 \%$ for Luxembourg at year level 2017 . At the opposite end, there is Croatia, Italy and 
C. G. Cosmulese, V. Grosu, E. Hlaciuc, A. Zhavoronok. The Influences of the Digital Revolution on the Educational System of the EU Countries

last place Romania, which for the year 2017 reaches a tertiary level of $26.3 \%$ on the segment of the population aged between 30-34 years, representing $65 \%$ of the average European level, a rate that saw an upward dynamics in 2013-2017.

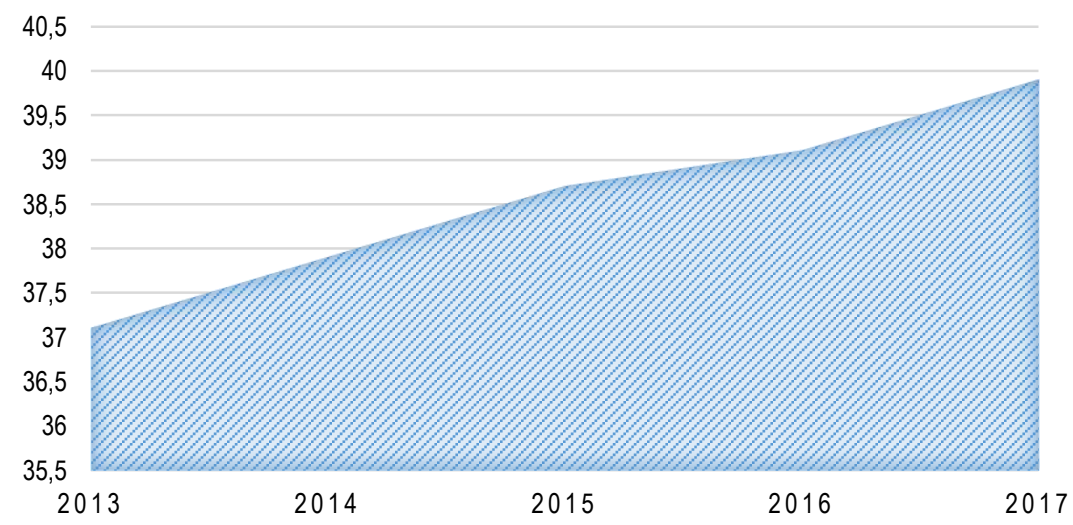

Figure 3. Level of tertiary education in the EU 28, age group 30-34

Source: processing by data provided by Eurostat (www.eurostat.eu).

Premature exit from the education system according to the gender of the participants have been declining over the period 2013-2017, reaching $11.9 \%$ of the EU population aged between 18-24 years in 2013 to $10.6 \%$ in 2017 ; the value is still above the target of $10 \%$ at the level of Horizon 2020 . The lowest abandonment rates are registered by Croatia (3.1\%), Slovenia (4.3\%), Switzerland $(4.5 \%)$, and the highest abandonment rates are registered by Turkey 32.5\%), Malta (18.6\%), Romania (18.1\%). Romania is distinguished by an increase in school dropout of $17.3 \%$ in 2013 , to $19.1 \%$ in 2015 , followed by a recovery period towards the end of the period, with a school dropout rate of $18.1 \%, 60 \%$ higher than the proposed target of $11.3 \%$.

In Romania, there is a presence of school dropout far above the EU average, even though European bodies have supported through various grant programs, several activities to reduce this phenomenon. The ICT Implementation Measures, funded under the Operational Competitiveness Program 2014-2020, the main vector, Priority Axis 2 - Information and Communication Technology (ICT) for a competitive digital economy, as set out in the National Digital Agenda for Romania (SNADR) must support investments in ICT and contribute to the overall objectives that ensure economic competitiveness and improve the standard of living for citizens. POC targets four main areas for ICT development: a) egovernance, interoperability, information security, cloud computing and social media, b) ICT in education, inclusion, health and culture, c) e-Commerce, ICT innovation, and d) Broadband infrastructure and digital services.

These measures have not reached their goal so far (the first half of 2018), as Romania has managed to absorb up to $16 \%$ of European funds 2014-2020.

c) The employment rate among graduates in the EU28, reached $80.2 \%$ in 2017 , with an increasing trend in the period 2013-2017 of 1.2\% annually. The highest rates for employment after graduation are recorded in Iceland $(94.8 \%)$, Malta $(94.5 \%)$, Germany $(90.9 \%)$ and the Netherlands $(90.4 \%)$. These rates indicate the high competitiveness of the education systems in the mentioned states, as well as the absorption capacity of their economy compared to the employment rates in Greece 
C. G. Cosmulese, V. Grosu, E. Hlaciuc, A. Zhavoronok. The Influences of the Digital Revolution on the Educational System of the EU Countries

$(52 \%)$ or Italy $(55.2 \%)$, Romania is close to the EU28 average, as a result of significant progress in the analysed period, from $67.2 \%$ to $76 \%$.

d) The level of early aged education as a percentage of inhabitants in the total population up to 4 years of age is high in the EU28, reaching $93.9 \%$ in 2017, with some countries reporting even $100 \%$ of the indicators (France and Malta), Romania is well below the European level with $85.5 \%$, being surpassed at the end of the ranking by Croatia $(75.1 \%)$, Greece $(75.2 \%)$, Finland $(75.1 \%)$ and Slovakia $(77.1 \%)$, and Macedonia, a non-EU member state, register for this indicator a rate of $31.3 \%$ the lowest rate at European level.

e) The level of ICT employment of specialists is 8,385,000 persons at EU28 level in $2017(3.86 \%$ of the total occupied population of the EU28), of which 6,940,000 are men, with a share of $82.8 \%$, and $1,444,000$ are women, with a share of $17.2 \%$. This indicator reveals a rather small development of ICT services to meet the needs of the educational system.

In this respect, it is necessary to develop a statistical model for evaluating the informational needs in education in relation to the demand for services, the traditional offer (by classical methods and the dynamics of the gap found by maximizing the informational factor provided by the digital revolution).

Model hypotheses:

1. The need for education, expressed through the percentage of a vacancy among the young population in the workplace, or employment in the learning process (NEET) varies in a proportionate relationship with the employment rate among graduates (EER) and the size of early-stage education (PEE);

2. The need for education, expressed through the percentage of vacancy among the young population in the workplace, or employment in the learning process (NEET) varies in a direction inversely proportional to the rate of education in the tertiary system, calculated for people aged 30-34 years (TEA) and with the rates of premature exit from the education system (EAL);

3. The evolution values of NEET can be correlated with an econometric model with regression variables ERG and PEE;

4. The function obtained through modelling can be assimilated to the service demand function and can be integrated into the offer function harmonized with the information factor.

The calculation of the model function can be determined on the basis of a cumulative regression equation of the form:

$$
F=\alpha \times V 1+\beta \times V 2+\varepsilon
$$

For the purpose of calculating the demand function, the percentage indicators of the following statistical indicators reported for 2017 by Eurostat at the level of the European Union and for each member state of the union, obtaining a total of 29 statistical observations presented in the table below:

Table 1. Statistical observations

\begin{tabular}{|l|c|c|c|c|c|}
\hline \multicolumn{1}{|c|}{ Country } & NEET \% & TEA \% & EAL \% & ERRG \% & PEE \% \\
\hline \multicolumn{1}{|c|}{1} & 2 & 3 & 4 & 5 & 6 \\
\hline European Union (current composition) & 14.3 & 39.9 & 10.6 & 80.2 & 93.9 \\
\hline Belgium & 12.1 & 45.9 & 8.9 & 81.9 & 98.0 \\
\hline Bulgaria & 18.6 & 32.8 & 12.7 & 77.7 & 87.1 \\
\hline Czech Republic & 8.3 & 34.2 & 6.7 & 89.9 & 86.1 \\
\hline Denmark & 9.2 & 48.8 & 8.8 & 82.9 & 98.0 \\
\hline Estonia & 12.3 & 48.4 & 10.8 & 81.5 & 90.0 \\
\hline Ireland & 13.2 & 53.5 & 5.1 & 83.6 & 99.1 \\
\hline
\end{tabular}


C. G. Cosmulese, V. Grosu, E. Hlaciuc, A. Zhavoronok. The Influences of the Digital Revolution on the Educational System of the EU Countries

\begin{tabular}{|c|c|c|c|c|c|}
\hline \multicolumn{6}{|c|}{ Continued Table 1} \\
\hline 1 & 2 & 3 & 4 & 5 & 6 \\
\hline $\begin{array}{l}\text { Germany (until } 1990 \text { former territory of the } \\
\text { FRG) }\end{array}$ & 8.6 & 34.0 & 10.1 & 90.9 & 96.5 \\
\hline Greece & 21.4 & 43.7 & 6.0 & 52.0 & 75.2 \\
\hline Spain & 17.1 & 41.2 & 18.3 & 71.9 & 97.4 \\
\hline France & 15.6 & 44.3 & 8.9 & 74.4 & 100.0 \\
\hline Croatia & 20.2 & 28.7 & 3.1 & 65.9 & 71.7 \\
\hline Italy & 25.7 & 26.9 & 14.0 & 55.2 & 99.2 \\
\hline Cyprus & 22.7 & 55.8 & 8.6 & 71.5 & 83.8 \\
\hline Latvia & 14.2 & 43.8 & 8.6 & 78.0 & 93.3 \\
\hline Lithuania & 12.1 & 58.0 & 5.4 & 83.9 & 84.8 \\
\hline Luxembourg & 8.2 & 52.7 & 7.3 & 88.5 & 97.8 \\
\hline Hungary & 14.1 & 32.1 & 12.5 & 84.7 & 94.5 \\
\hline Malta & 8.5 & 30.0 & 18.6 & 94.5 & 100.0 \\
\hline Netherlands & 5.3 & 47.9 & 7.1 & 90.4 & 99.6 \\
\hline Austria & 8.1 & 40.8 & 7.4 & 89.4 & 93.8 \\
\hline Poland & 12.8 & 45.7 & 5.0 & 82.1 & 84.3 \\
\hline Portugal & 13.0 & 33.5 & 12.6 & 80.7 & 95.0 \\
\hline Romania & 19.3 & 26.3 & 18.1 & 76.0 & 85.5 \\
\hline Slovenia & 8.0 & 46.4 & 4.3 & 81.6 & 90.9 \\
\hline Slovakia & 15.3 & 34.3 & 9.3 & 81.5 & 77.1 \\
\hline Finland & 12.9 & 44.6 & 8.2 & 77.0 & 75.1 \\
\hline Sweden & 8.2 & 51.3 & 7.7 & 88.3 & 95.9 \\
\hline United Kingdom & 13.2 & 48.3 & 10.6 & 86.6 & 97.3 \\
\hline
\end{tabular}

Source: processing by data provided by INS (www.insse.ro).

Results. The data were modelled through the GRETL statistical program, obtaining a model based on the smallest squares method in 2 phases whose regression equation is defined as:

$$
\begin{aligned}
& \text { NEET }=-0.272^{*} \text { ERRG }+0.384^{*} \text { PEE } \\
& (0.102) \quad(0.0896)
\end{aligned}
$$

$\mathrm{n}=29, \mathrm{R}$-squared $=0.884$, (standard errors in parentheses)

where, the dependency variable (NEET) is represented by the need for education expressed by the percentage of a vacancy among the young population in the workplace or employment in the educational process; the regression variable 1 (EERG) is represented by the employment rate among graduates; the regression variable 2 (EPE) is represented by the size of education for younger ages4; the instrumented variable 1 (TEA) is the rate of education in the tertiary system, calculated for people aged 30-34 years; the instrumented variable 2(EAL) is the rate of premature exit from the education system; error is normally distributed, the heteroscedasticity test reported absence of the phenomenon for the null hypothesis).

The statistical tests are shown in table 2 . 
C. G. Cosmulese, V. Grosu, E. Hlaciuc, A. Zhavoronok. The Influences of the Digital Revolution on the Educational System of the EU Countries

Table 2. Statistical tests for Model 1: TSLS, using observations 1-29

\begin{tabular}{|c|c|c|c|c|c|}
\hline & Coefficient & Std. Error & t-ratio & $p$-value & \\
\hline ERRG & -0.272323 & 0.101582 & -2.681 & 0.0124 & ** \\
\hline PEE & 0.384144 & 0.0896179 & 4.286 & 0.0002 & $\star \star \star *$ \\
\hline \multicolumn{2}{|l|}{ Mean dependent var } & 13.53448 & S.D. dependent var & \multicolumn{2}{|r|}{5.023180} \\
\hline \multicolumn{2}{|l|}{ Sum squared resid } & 699.6471 & S.E. of regression & \multicolumn{2}{|r|}{5.090467} \\
\hline \multicolumn{2}{|l|}{ Uncentered R-squared } & 0.883756 & Centered R-squared & \multicolumn{2}{|r|}{0.009708} \\
\hline \multicolumn{2}{|l|}{$F(2,27)$} & 102.6352 & P-value(F) & \multicolumn{2}{|r|}{$2.41 \mathrm{e}-13$} \\
\hline \multicolumn{2}{|l|}{ Log-likelihood } & -87.30678 & Akaike criterion & \multicolumn{2}{|r|}{178.6136} \\
\hline \multicolumn{2}{|l|}{ Schwarz criterion } & 181.3482 & Hannan-Quinn & & 179.4700 \\
\hline
\end{tabular}

Sargan over-identification test -

Null hypothesis: all instruments are valid

Test statistic: $L M=2.56045$ with $p$-value $=P($ Chi-square $(2)>2.56045)=0.277975$

Test for normality of residual -

Null hypothesis: error is normally distributed

Test statistic: Chi-square $(2)=2.67796$ with $p$-value $=0.262113$

Pesaran-Taylor test for heteroskedasticity -

Null hypothesis: heteroskedasticity not present

Asymptotic test statistic: $z=1.34175$ with $p$-value $=0.179676$

Note: Dependent variable: NEET, Instruments: ERRG PEE TEA EAL

Source: developed by the authors through

The $Q-Q$ plot distribution graphs reveal a right-handed sweep of the homogeneous trend to demonstrate the validity of the model:

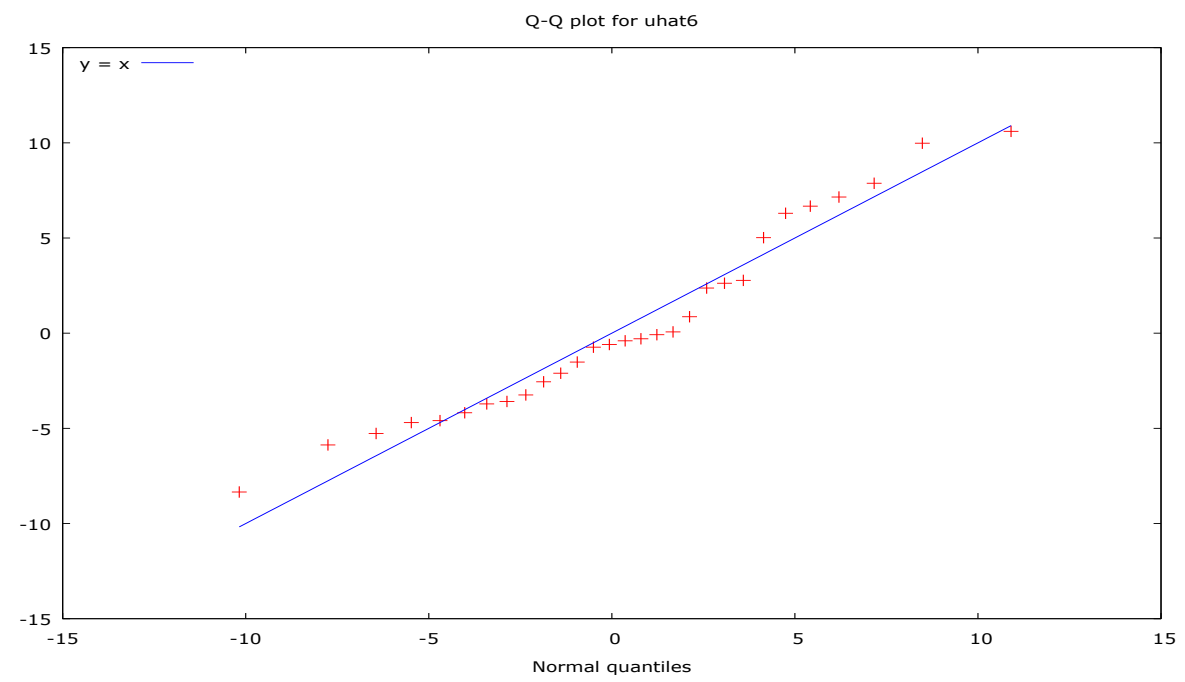

Figure 5. $Q-Q$ plot diagram for the dependent variable

Source: developed by the authors through the GRETL program. 
C. G. Cosmulese, V. Grosu, E. Hlaciuc, A. Zhavoronok. The Influences of the Digital Revolution on the Educational System of the EU Countries

The histogram distribution reveals the homogeneity of data that conforms to the trend gaussian curve, as shown below:

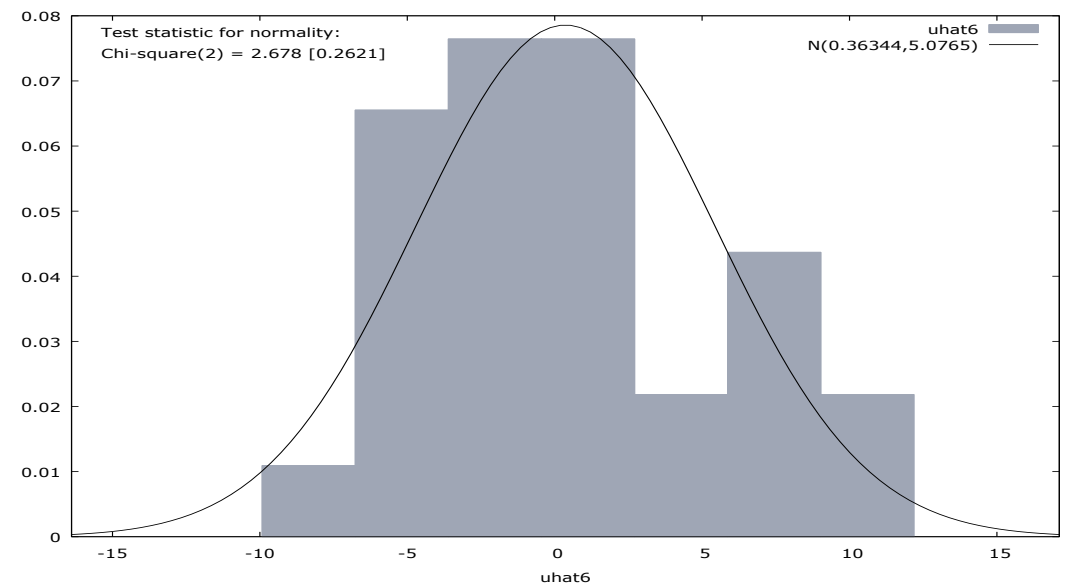

Figure 6. Histogram distribution of data

Source: Developed by the authors through the GRETL program.

The function obtained through modelling can be assimilated to the service demand function and can be integrated into the offer function harmonized with the information factor.

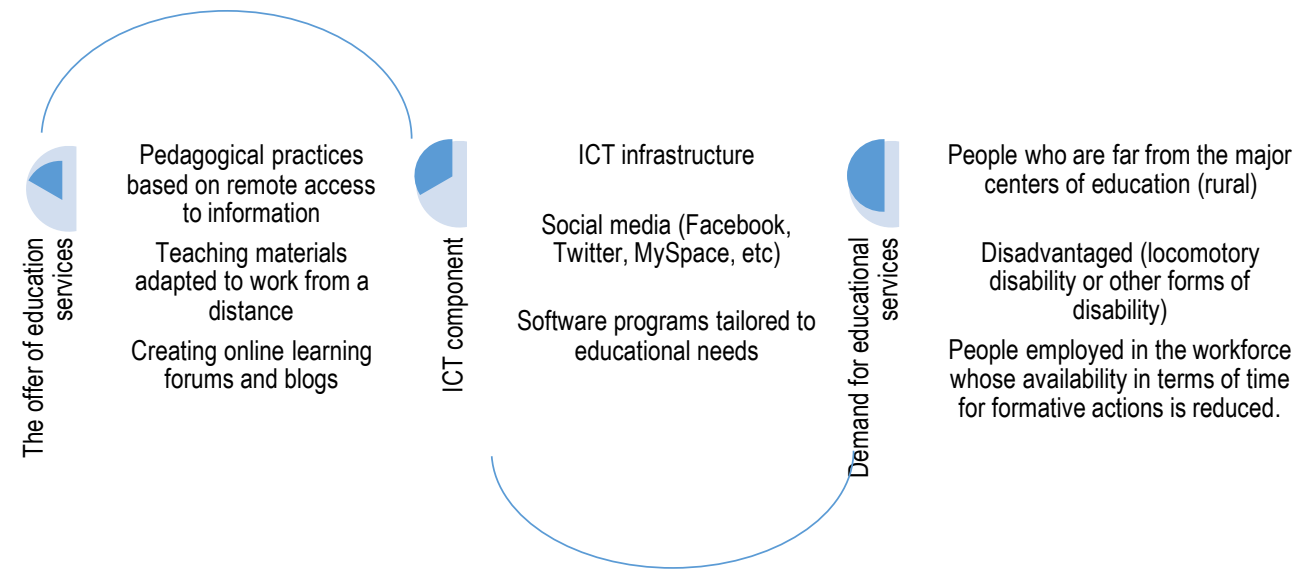

Figure 7. The offer function harmonized with the information factor

Source: the authors' development.

The integrated function is of the form:

$$
\mathrm{O}_{\mathrm{fe}}=\lim _{C E \rightarrow \infty}\left(1+\frac{1}{C E(N E E T)}\right)^{T I C}
$$

where: $\mathrm{O}_{\mathrm{fe}}$ - Educational services offer, CE (NEET) - demand for educational services, TIC - the information factor. 
C. G. Cosmulese, V. Grosu, E. Hlaciuc, A. Zhavoronok. The Influences of the Digital Revolution on the Educational System of the EU Countries

The function is maximized in the context of maximizing the ICT component for a demand defined according to the CE model equation (NEET) $=-0.272^{*} E R R G+0.384^{*} \mathrm{PEE}$.

As shown by the proposed econometric model, the hypotheses presented in the paper have been validated, the proposed model is homogeneous, well-defined and relevant to the studied phenomenon.

This model is particularly useful tools for testing how robust strategies are in the face of multiple possible futures, and for detecting signals of the actual, emergent future.

Conclusions. This paper shows that there is a need to assimilate the European approaches in the field of digital evolution, a necessity which varies according to the economic development of each member state, Romania being ranked in the chapter of assimilation of the objectives of the open education agenda in the second part of the European ranking, including based on the low absorption rates provided for Union programs in this area.

The digital revolution is a field of great interest and profoundly beneficial to the education systems in the Member States and we believe that by better addressing educational policies and adapting them to the information factor, system increases can be achieved by attracting the excess demand for educational services.

Demand can be predicted on the basis of the proposed model, which is an innovative, impact and significant model for the studied phenomenon.

This research study represents a contribution to the field of management of public utility companies and can be useful for educational institutions, students, the labor market and the general public providing a starting point for further in-depth research in this area.

Author Contributions: conceptualization, V. G; data curation, E. H. methodology, C. G. C. and V. G.; supervision, V. G.; investigation, A. Z., and C. G. C.; formal analysis, V. G. and A. Z.; validation, V. G. and E. H.; visualization, V. G. and A.Z.; writing-original draft preparation, V. G. and C. G. C.; writing - review and editing, A. Z. and C. G. C.

Funding: This work is supported by project POCU 125040, entitled «Development of the tertiary university education to support the economic growth - PROGRESSIO», co-financed by the European Social Fund under the Human Capital Operational Program 2014-2020.

\section{References}

Abou El-Seoud, M. S.Taj-Eddin, A.T.F. I.; Seddiek, N., El-Khouly, M.M., \& Nosseir, A. (2014). E-Learning and students' motivation: a research study on the effect of e-learning on higher education, International Journal of Emerging Technologies in Learning, 9(4), 20-26. Retrieved from http://www.online-journals.org/index.php/i-jet/article/viewFile/3465/3211

Ahuja, P. (2015). The digital revolution and its impact on education, International Journal Of Business Management, 2(1), 1684-1692. Retrieved from http://www.ijbm.co.in/downloads/vol2-issue2/59.pdf.

Badicu, G., \& Mihaila, S. (2016). Study regarding the relevance of the accounting subjects in the economic vocational training of non-accountant specialists The Audit Financiar Journal, Chamber of Financial Auditors of Romania, 14(140), 897-897.

Bennett, S. J., Maton, K. A. \& Kervin, L. K. (2008). The 'digital natives' debate: a critical review of the evidence. British Journal of Educational Technology, 39 (5), 775-786. Retrieved from https://ro.uow.edu.au/cgi/viewcontent.cgi?article $=2465 \&$ context=edupapers.

Benta, D., \& Bologa, G., Dzitac, S., Dzitac I. (2015).University Level Learning and Teaching via E-Learning Platforms, Procedia Computer Science, 55, 1366 - 1373. https://doi.org/10.1016/j.procs.2015.07.123

Burciu, A., \& Kicsi, R. (2015). Knowledge as a distinctive resource of competitive advantage, Ecoforum Journal, 4.Retrieved fromhttp://ecoforumjournal.ro/index.php/eco/article/view/21

Çakmak, T., Ozel, N., \& Yılmaz, M. (2013). Evaluation of the open course ware initiatives within the scope of digital literacy skills: Turkish Open CourseWare Consortium Case, Procedia - Social and Behavioral Sciences. 83, 65-70. https://doi.org/10.1016/j.sbspro.2013.06.014

Calvani, A., Fini, A. \& Ranieri, M. (2009).Valutare la competenza digitale. Modelli teorici e strumenti applicativi [Evaluate 


\section{G. Cosmulese, V. Grosu, E. Hlaciuc, A. Zhavoronok. The Influences of the Digital Revolution on the Educational System of the EU Countries}

digital competence. Theoretical models and application tools].TD-Tecnologie Didattiche, 48, 39-46.

Ciubotariu, M.S. (2011). Etica şi moralitate în profesia contabila [Ethics and morality in the accounting profession], Umanism, Educaţie, Resurse Umane (UERU), 6-7 May, a „Ş̧tefan cel Mare University of Suceava, Didactica şi Pedagogica, Bucharesti, ISBN 978-973-30-2933-5, pp. 221-228.

Das, A. K. (2011). Emergence of open educational resources (OER) in India and its impact on lifelong learning. Library $\mathrm{Hi}$ Tech News, 28(5), 10-15. Retrieved from https://www.researchgate.net/publication/238599328_Emergence_of_open_ educational_resources_OER_in_India_and_its_impact_on_lifelong_learning.

Dicusar, L., Dicusar, I. (2011). Impactul economic al tehnologiei informaţiei şi comunicaţilor în educaţie [The economic impact of information and communication technology in education], Fizica si Tehnologiile Moderne Magazine, 9(1-2), 56-63. Retrieved from http://sfm.asm.md/ftm/vol9nr1-2/6\%20tehnologia\%20informatiei.pdf.

European Commission (2018). Communication from the Commission to the European Parliament, the Council, the European Economic and Social Committee and the Committee of the Regions on the Digital Education Action Plan, Working Document, Brussels, Retrieved from https://ec.europa.eu/education/sites/education/files/swd-digital-education-action-plan.pdf.

Fat, S., \& Vlada, M. (2012). Consideraţii privind impactul programelor educaționale asupra culturii sociale a școlii [Considerations on the impact of educational programs on the social culture of the school]. Retrieved from http://www.icvl.eu/2012/disc/cniv/documente/pdf/sectiuneaA/sectiuneaA_lucrarea5.pdf

Ferri, P. (2013). L'impatto della rivoluzione digitale e delle nuove tecnologie della comunicazione sui paradigmi epistemologici e sulle pratiche della didattica e della formazione [The impact of the digital revolution and new communication technologies on epistemological paradigms and on teaching and training practices]. Retrieved from http://www.novecento.org/dossier/la-storia-nellera-digitale/paolo-ferri-limpatto-della-rivoluzione-digitale-e-delle-nuove-tecnologie/. [

Gilster, P. (1997). Digital literacy. New York: Wiley Computer Publications.

Goulão, M. D., \& Fombona, J., Digital Literacy and Adults Learners' Perception: The Case of a Second Chance to University. Procedia - Social and Behavioral Sciences, 2012, 46, 350-355.

Horizon Report Europe. (2014). Schools Edition examines trends, challenges, and technologies for their potential impact on and use in teaching, learning, and creative inquiry. Retrieved from http://publications.europa.eu/resource/cellar/1eda751c-a4404b5e-8b53-04243d3ff8b3.0001.02/DOC_1.

lancu, S. (2005). Impactul social al utilizarii tehnologiei informaţiei şi comunicaţilor [The social impact of the use of information and communication technology], Sociologie Magazine, XVI, 5 -6, 449-468. Retrieved from http://www.revistadesociologie.ro/pdf-uri/nr.5-6-2005/art2\%20Stefan\%20lancu.pdf.

Internet Users in the world by Regions (2019). Retrieved from https://www.internetworldstats.com/stats.htm

Kakoty, S., Lal, M., \& Sarma, S.K. (2011). E-learning as a research area: an analytical approach, international Journal of Advanced Computer Science and Applications, 2(9), 144-148. Retrieved from https://pdfs.semanticscholar.org/8d18/ be2a55ac3c67142ec4093cd6386c1d395096.pdf

Kapenieks, J. (2013). User-friendly e-learning environment for educational action research, Procedia Computer Science, 26, 121-142.

Lane, A. (2010). Designing for innovation around OER. Journal of Interactive Media in Education, 1-10. Retrieved from https://www-jime.open.ac.uk/articles/10.5334/2010-2/.

Mihaila, S., \& Badicu, G. (2016). Necesitatea intercorelarii mediului universitar cu cel profesional [The need to interconnect the university with the professional one], Fostering Knowledge Triangle in Moldova Conference Proceedings, 81-87. Retrieved fromtoknowpress.net

Nastase, C. (2012). The interactions between entrepreneurial education and business environment, The USV Annals

of Economics and Public Administration, 12, 2(16), 7-12.

National Institute of Statistics. Retrieved from http://www.insse.ro/cms/ro

Prensky, M. (2001). Digital Natives, Digital Immigrants, part II: do they really Think Differently?, On the Horizon, 9(6),15-24.

Shkarlet, S., Kholiavko, N., Dubyna, M., \& Zhuk, O. (2019). Innovation, Education, Research Components of the Evaluation of Information Economy Development (as Exemplified by Eastern Partnership Countries). Marketing and Management of Innovations, 1, 70-83. http://doi.org/10.21272/mmi.2019.1-06

Socoliuc, M. (2016a). Interpretations related to the development of the economic and financial communication on a group level, Ecoforum Journal, 5. Retrieved from http://ecoforumjournal.ro/index.php/eco/article/view/443

Socoliuc, M. (2016b). The Particularities Of Financial Communication In The Retails Companies, Ecoforum Journal, 5(2). Retrieved from http://www.ecoforumjournal.ro/index.php/eco/article/view/444

The International Computer and Information Literacy Study (ICILS) Main findings and implications for education policies in Europe, 2014, Retrieved from http://ec.europa.eu/dgs/education_culture/repository/education/library/study/2014/ec-icils_en.pdf.

Togoe G. D., Mateş, D., Manescu, D., \& Mileva, V. (2013). Impact of ethical values promoted by professional accountants on 
C. G. Cosmulese, V. Grosu, E. Hlaciuc, A. Zhavoronok. The Influences of the Digital Revolution on the Educational System of the EU Countries

the organizational culture, The Journal of the Faculty of Economics - Economic, Oradea, 1 (1 (July), 1280-1285.

Institutul Natịonal de Statistică (2019). Statistical data. Retrieved from http://www.insse.ro/cms/ro

Космулес Крістіна Габріела, Ph.D., Сучавський університет імені Штефьана чел Маре (Румунія);

Гросу Вероніка, D.Sc., профресор, Сучавський університет імені Штефрана чел Маре (Румунія);

Хлачук Елена, D.SC., профресор, Сучавський університет імені Штефрана чел Маре (Румунія);

Жаворонок Артур, к.е.н., доцент, Чернівецький національний університет імені Юрія Федьковича (Україна).

Вплив цифрової революції на систему освіти країн ЄС

У контексті програм розвитку інформаційних навичок, які розробляються $Є С$, зростає інтерес до придбання та використання иифрових компетенцій як фактору впливу на систему освіти на всіх її рівнях формування. Дане дослідження має на меті проаналізувати еволюцію цифрових спеціалізацій, що генеруються цифрровою еволюцією, паралельно з розвитком системи освіти, шляхом статистичного аналізу основних показників, які були зареєстровані на рівні ЄС щодо ранньої відмови від освіти, рівня зайнятості випускників, залучення IT-спеціалістів за гендерною ознакою, участь дорослих у ґендерному навчанні та інші показники впливу, що демонструють потенціал населення в иифровій сфрері, шляхом використання IКТ-рішень. Об'єктом дослідження були статистичні показники, зафіксовані Євростатом на 2017 рік на рівні Європейського Союзу, для кожної держави-члена союзу, отримавши в иілому 29 статистичних спостережень. Дані моделювали за допомогою статистичної програми GRETL, отримуючи модель на основі методу найменших квадратів у 2 фази. Ця стаття показує, що існує потреба в засвоєнні європейських підходів у ссфері цифррової еволюиії, необхідності, яка залежить від економічного розвитку кожної країни-члена. Румунія входить до розділу засвоєння цілей програми відкритої освіти у другій частині європейського рейтингу, в тому числі на основі низьких коефіцієнтів поглинання, передбачених для програм Союзу в цій сфрері. Дослідження теоретично та емпірично підтверджує, що функиія, отримана за допомогою моделювання, може бути засвоєна функцією попиту на послуги і може бути інтегрована в фрункцію пропозиції, гармонізовану з інформаційним фактором. Це дослідження $є$ внеском у сфреру управління комунальними підприємствами і може бути корисним для навчальних закладів, студентів, ринку праці та широкої громадськості, що є відправною точкою для подальших поглиблених досліджень у цій сфрері.

Ключові слова: система освіти, цифрова революція, економічний розвиток, Порядок денний ЄС.

Manuscript received: 03.07.2019

(c) The author(s) 2019. This article is published with open access at Sumy State University. 